\title{
PERSONALITAS HUKUM WORLD TRADE ORGANIZATION BAGI NEGARA BERKEMBANG TERKAIT SISTEM PERDAGANGAN ANTAR NEGARA
}

\author{
Aldo Rico Geraldi \\ Jurusan Ilmu Hukum, Fakultas Hukum dan Ilmu Sosial \\ Universitas Pendidikan Ganesha \\ Email: aldoricogeraldi91@gmail.com \\ Luh Putu Purnama Ning Widhi \\ Universitas Udayana Denpasar \\ Email : lulu.galuhpurnama@gmail.com
}

\begin{abstract}
ABSTRAK
Penelitian ini bertujuan untuk menganalisis personalitas hukum World Trade Organization terkait transaksi perdagangan antar negara. Selain itu, penelitian ini juga menganalisis peran World Trade Organization bagi negara berkembang dalam sistem perdagangan antar negara.

Penelitian ini menggunakan penelitian hukum normatif dengan mengkaji suatu aturan-aturan, prinsip-prinsip, dan doktrin-doktrin hukum yang terkait dengan permasalahan dalam penelitian ini untuk menghasilkan suatu argumentasi. Pengumpulan data dilakukan dengan menggunakan metode studi kepustakaan dengan mengumpulkan bahan hukum dan informasi yang berupa bahan-bahan hukum primer, sekunder, maupun tersier. Dalam rangka mendapatkan pemaparan yang jelas, data tersebut kemudian disusun secara sistematis dan dianalisis dengan menggunakan metode deskriptif.

Hasil penelitian ini menunjukkan bahwa artikel VIII Marakesh Agreement menyebutkan bahwa status WTO sebagai organisasi internasional memiliki personalitas hukum atau legal personality untuk mengimplementasikan fungsi organisasi. Selanjutnya, mengenai peran World Trade Organization memberikan pengaruh bagi perdagangan internasional terkait dengan adanya dorongan bagi persaingan bebas, sistem WTO dapat memberikan kontribusi pada pembangunan, WTO dapat meningkatkan prediktabilitas, serta mendorong terciptanya perdamaian dalam perdagangan antar negara.
\end{abstract}

Kata Kunci: WTO, Personalitas Hukum, Perdagangan, Negara Berkembang

\section{ABSTRACT}

This research aims to analyze the legal personality of World Trade Organization related to inter-state trade transactions. In addition, this study also analyzes the role of the World Trade Organization for developing countries in the inter-state trade system.

This research uses normative legal research by examining a rule, principles, and legal doctrines related to the problems in this research to generate an argumentation. The data were collected by using literature study method by 
collecting legal and information materials in the form of primary, secondary, and tertiary legal materials. In order to obtain clear exposure, then the data is arranged systematically and analyzed using descriptive method.

The results of this research indicate that the article VIII Marakesh Agreement states that the status of the WTO as an international organization has the legal personality to implement organizational functions. Furthermore, regarding the role of the World Trade Organization affecting international trade in relation to the impetus for free competition, the WTO system can contribute to development, the WTO can increase predictability, and encourage the creation of peace in inter-state trade

Keywords: WTO, Legal Personality, Trade, Developing Countries

\section{Pendahuluan}

Kebijakan perdagangan merupakan bagian integral dari pembangunan nasional yang dilakukan dengan memperhatikan gejala dan perkembangan di negara lain yang berpengaruh pada perekonomian nasional. Perkembangan saat ini telah menciptakan ekonomi nasional yang beragam dan berdaya saing. Ekonomi nasional telah mampu menghasilkan produk-produk yang makin beragam dalam jumlah dan kualitas yang semakin meningkat. Kepentingan utama ekonomi nasional adalah tersedianya pasar yang luas, bebas, dan terbuka yang mengikuti perkembangan ekonomi dunia yang semakin meningkat serta sistem penyelenggaraan perdagangan antar bangsa dan kebijakan pemerintah yang menciptakan iklim yang sehat (Syahmin, 2006:11-12). Perdagangan internasional merupakan faktor yang sangat penting bagi setiap negara. Negara ataupun subjek hukum lain sebagai pelaku perdagangan memiliki berbagai motif dalam melakukan transaksi dagang internasional (Huala adolf, 2005:2).

Perdagangan internasional yang dilakukan oleh negara-negara berpengaruh terhadap besar dan jayanya negara-negara di dunia, sebagai contoh kejayaan China masa lalu yang tidak terlepas dari kebijakan dagang yang terkenal dengan sebutan silk road atau jalan suteranya (Jonathan Reuvid, 1997:XV.). Selain kejayaan China, tranksaksi dagang internasional juga sangat penting bagi Indonesia yang dapat dilihat dari Amanna Gappa, kepala suku bugis yang sadar akan pentingnya dagang dan pelayaran bagi kesejahteraan sukunya (PH.OL.Tobing, 1977:154.). Selanjutnya, di Eropa aktivitas perdagangan internasional telah tercatat sejak abad keduabelas, tetapi perdagangan internasional mulai berkembang pada awal abad keenambelas. Perdagangan internasional mulai berkembang pada awal abad keenambelas (Rusli Pandika, 2010:20).

Perdagangan internasional memiliki ciri khas adanya hubungan dagang yang dilakukan 
antar lintas batas-batas negara yang dilakukan oleh para pelaku usaha dengan mengikuti suatu sistem tertentu dan spesifik (John Braithwaite dan Peter Drahos, 2000:24-25.). Dalam perdagangan internasional, eksistensi suatu sistem merupakan patron yang membentuk dan mengarahkan kegiatan-kegiatan perdagangan ke dalam tujuan-tujuan tertentu yang diinginkan (Christhophorus Barutu, 2007:5). Perdagangan internasional mempunyai peranan yang cukup besar bagi pertumbuhan ekonomi negara (Nopirin, 2000:125-126.). Selain itu, perdagangan dapat menjadi mesin bagi pertumbuhan. Jika aktifitas perdagangan internasional adalah ekspor dan impor, maka salah satu dari komponen tersebut atau keduaduanya dapat menjadi motor penggerak bagi pertumbuhan (Salvatore Dominick, 2007:8). Selanjutnya, perdagangan internasional memberi peluang lebih baik bagi sebuah masyarakat dibandingkan dengan ekonomi yang mengandalkan kekuatan sendiri (M. Luthfi Hamidi, 2007:3).

Transaksi perdagangan internasional merupakan suatu faktor penting dan merupakan suatu kebebasan fundamental (Huala Adolf, 2002:1). Oleh karena itu, diperlukan hubungan perdagangan antar negara yang tertib dan adil. Keadilan mengandung nilai moral universal yang merupakan hak dan kebutuhan dasar manusia di seluruh dunia (Kevin E. Hodges dan Daniel P. Sulmasy, 2013:1). Nilai moral keadilan tersebut menjadi cita-cita setiap bangsa yang didalamnya terdapat kepentingan berbagai golongan (Richard A. Posner, 1999:19). Dalam hal ini, keadilan menjadi kesepakatan diantara berbagai unsur masyarakat yang menginginkan kehidupan bernegara yang adil dan makmur. Demikian pula dalam sistem hukum perdagangan internasional yang merupakan salah satu sistem sosial. untuk mewujudkan ketertiban dan keadilan di bidang perdagangan internasional, diperlukan aturanaturan yang mampu menjaga serta memelihara hak-hak dan kewajiban para pelaku perdagangan internasional. Perangkat hukum internaisonal yang mengatur hubungan dagang antar negara terkandung dalam dokumen GATT (General Agreement on Tariffs and Trade).

Terbentuknya GATT selepas perang dunia kedua adalah upaya untuk memberikan rule of the road pada hubungan perdagangan Internasional yang mengalami kekacauan akibat terjadinya perang tarif bahkan perang dagang pada masa-masa sebelum perang (Hata, 2007:60). Sistem yang terwujud tersebut, semula hanya dianggap sebagai sistem interim, yang dapat berkembang secara pragmatis sehingga menjadi sesuatu yang kompleks dan telah mengalami perluasan, baik dari segi cakupan substantif maupun dari segi kelembagaan. Setelah perundingan Uruguay Round (1986-1994) selesai, maka negara anggota GATT sepakat pula untuk 
membentuk suatu lembaga baru yang diberi nama World Trade Organization (WTO) sebagai lembaga penerus GATT (H.S. Kartadjoemena, 2000:3-4).

\section{Rumusan Masalah}

Berdasarkan latar belakang yang telah diuraikan di atas, penulis mengangkat dua permasalahan yang meliputi:
1. Bagaimana personalitas hukum World Trade Organization terkait transaksi perdagangan antar negara?
2. Bagaimana World Trade Organization berperan bagi negara berkembang dalam sistem perdagangan antar negara?

\section{Metode Penelitian}

Penelitian ini mengguunakan penelitian hukum normatif dengan mengkaji suatu aturan-aturan, prinsip-prinsip, dan doktrindoktrin hukum yang terkait dengan permasalahan dalam penelitian ini untuk menghasilkan suatu argumentasi (Mukti Fajar dan Yulianto Achmad, 2010:34). Pengumpulan data dilakukan dengan menggunakan metode studi kepustakaan dengan mengumpulkan bahan hukum dan informasi yang berupa bahanbahan hukum primer, sekunder, maupun tersier (Ronny Hanitijo, 1991:93). Dalam rangka mendapatkan pemaparan yang jelas, data tersebut kemudian disusun secara sistematis dan dianalisis dengan menggunakan metode deskriptif.

\section{Pembahasan}

\section{Personalitas hukum World Trade Organization terkait transaksi perdagangan antar negara}

Perjanjian perdagangan internasional pertama yang diakui dunia adalah Perjanjian Umum tentang Tarif dan Perdagangan (GATT) pada tahun 1948. Pada awalnya GATT ditujukan untuk membentuk International Trade Organization (ITO), suatu badan khusus PBB (Huala adolf, 2005:103). Pertemuan Bretton Woods atau United Nations Monetary and Financial Conference di bulan Juli 1944 di Bretton Woods, New Hampshire, Amerika Serikat, dihadiri wakil-wakil dari empat puluh empat negara untuk merumuskan financial arrangements yang diperlukan untuk membangun kembali perekonomian dunia dan meningkatkan perdagangan internasional sehabis perang dunia kedua menunjukkan pada tiga pilar utama pendukung pertumbuhan perekonomian dunia berupa satu tata moneter dunia untuk menjamin terciptanya stabilitas moneter dan nilai tukar dengan menyediakan bantuan keuangan jangka pendek bagi negara-negara yang mengalami kesulitan neraca pembayaran yang diwujudkan dengan pembentukan International Monetary Fund (IMF) (Gofar Bain, 2001:14). Selain itu, tersedianya dana jangka panjang bagi negaranegara yang memerlukan bantuan luar negeri bagi keperluan pembangunan ekonomi mereka yang diwujudkan dengan pembentukan International Bank 
for Reconstruction and Development (Word Bank) atau IBRD (Ibid).

Pilar utama pendukung pertumbuhan perekonomian dunia lainnya berupa berfungsinya suatu sistem perdagangan internasional yang bebas dan terbuka yang semula ingin diwujudkan tetapi tidak berhasil, melalui pembentukan International Trade Organisation (ITO) atau Organisasi Perdagangan Internasional (Ibid). Meskipun tidak berhasil membentuk International Trade Organization yang dimaksud sebagai salah satu pilar dari system Bretton Woods bersama dua pilar lainnya yaitu the International Monetary Fund (IMF) dan the Word Bank, namun masyarakat BangsaBangsa telah memfungsikan the General Agreement on Tariffs and Trade yang dirancang bersama dengan piagam International Trade Organization dan menjadi principal institution bagi perdagangan internasional (John H. Jackson, 2000:37).

GATT adalah suatu sistem, forum, dan lembaga internasional di bidang perdagangan. Sistem tersebut mulai diwujudkan tahun 1947 dan mulai beroperasi tahun 1948. Pembentukan GATT dimulai dari pengalaman pahit depresi ekonomi dunia pada dasawarsa 1930-an, yang diikuti dengan pemberlakuan proteksi perdagangan oleh negara-negara besar. Sejak tahun 1948-1994, GATT mengadakan 7 (tujuh) putaran perundingan perdagangan multilateral dengan tujuan memfasilitasi perdagangan internasional (Mochamad Slamet
Hidayat, 6). Serangkaian persetujuan mengenai hambatan non-tarif telah muncul di berbagai perundingan, yang dalam beberapa kasus menginterpretasikan peraturan GATT yang sudah ada (Hira Jhamtani, 2005:3).

Perubahan dari GATT ke WTO berdampak luas terhadap bidang hukum perdagangan internasional dikarenakan bidang pengaturan yang tercakup dalam WTO lebih komplek yang tidak hanya mengatur mengenai tarif dan barang, tetapi juga mengatur mengenai jasa, hak kekayaan intelektual, penanaman modal, lingkungan, dan lain sebagainya (Ray August, 2000:355-36). Sebelumnya, hukum perdagangan internasional muncul dari praktik para pedagang. Hukum yang diciptakan oleh para pedagang biasanya disebut lex mercatoria (law of merchant) (United Nations, 1966:21). Pada awal perkembangannya, lex mercatoria muncul karena lahirnya aturanaturan yang timbul dari kebiasaan dalam berbagai pekan raya atau the law of the fairs. Selain itu juga dikarenakan lahirnya kebiasaankebiasaan dalam hukum laut dan kebiasaan-kebiasaan yang timbul dari praktik penyelesaian snegketa-sengketa di bidang perdagangan serta berperannya notaris atau public notary dalam memberi pelayanan jasa-jasa hukum dagang (Schmitthoff, 1968:106).

Berdirinya WTO dalam Uruguay Round tahun 1994 tersebut (Raj Bhala, 2001:201), telah menjadi salah satu organisasi 
internasional yang berpengaruh dalam kerangka rezim internasional dan globalisasi ekonomi. Melalui WTO dalam Uruguay Round itu (Uruguay Round Trade Agreement, H.R. Doc. No. 316, 103d Cong., 2d Sess, 656-667, September 27, 1994), membuat negara-negara yang menandatangani perjanjian WTO telah masuk dalam ekonomi global yang wajib mengikuti rezim internasional tersebut (James E. Darton, 2011:2). Karena sistem perdagangan dalam kerangka WTO itu merupakan suatu rule based system dengan perjanjianperjanjian multilateral yang disepakati bersama yang sifatnya terintegrasi dan single undertaking (Peter van den Bossche, dkk, 2010:xi). Salah satu elemen yang paling penting dari rules-based sistem perdagangan multilateral dalam kerangka WTO itu adalah sistem penyelesaian sengketa (Rufus Yerxa, 2005:3).

WTO sebagai organisasi perdagangan dunia bertujuan mewujudkan liberalisasi perdagangan melalui berbagai macam cara termasuk penghapusan hambatan perdagangan, baik hambatan tarif maupun non tarif, serta mengurangi tindakan diskriminasi dalam hubungan dagang internasional (Paragraf 3 The Marrakesh Agreement Establishing the World Trade Organisation.). Namun, liberalisasi perdagangan menimbulkan ketidakadilan yang khususnya dirasakan oleh negaranegara berkembang, seperti negara-negara berkembang diminta untuk membuka akses pasarnya secara luas dan cepat sementara negara-negara maju cenderung bermufakat untuk menjaga pasar mereka dari produk-produk yang berasal dari negara berkembang yang mampu bersaing dengan produk negara maju seperti produk pertanian, tekstil, dan pakaian, serta kurangnya kemampuan negara berkembang dalam memanfaatkan liberalisasi perdagangan akibat dair kurangnya sumber daya dan informasi (Peter Van Den Bossche, 2005:15-16).

Pendirian WTO ditujukan untuk mendorong arus perdagangan antar negara melalui pengurangan tariff dan hambatan dalam perdagangan serta membatasi perlakuan diskriminasi dalam hubungan perdagangan internasional. WTO memiliki beberapa tujuan penting dalam perdagangan internasional yaitu untuk mendorong arus perdagangan antar negara, dengan mengurangi dan menghapus berbagai hambatan yang dapat mengganggu kelancaran arus perdagangan barang dan jasa. Selain itu, menfasilitasi perundingan dengan menyediakan forum negosiasi yang lebih permanen. Hal ini mengingat bahwa perundingan perdagangan internasional di masa lalu, prosesnya sangat kompleks dan memakan waktu. Selanjutnya adalah untuk penyelesaian sengketa, mengingat hubungan dagang sering menimbulkan konflik-konflik kepentingan. Meskipun sudah ada persetujuan- 
persetujuan dalam WTO yang sudah disepakati anggotanya, masih dimungkinkan terjadi perbedaan interpretasi dan pelanggaran sehingga diperlukan prosedur legal penyelesaian sengketa yang netral dan disepakati bersama (Huala Adolf, 2004:114).

Mengenai fungsi-fungsi yang dimiliki oleh WTO antara lain untuk mendukung pelaksanaan, pengaturan, dan penyelenggaraan persetujuan yang telah dicapai untuk memujudkan sasaran perjanjian tersebut. Selain itu sebagai forum perundingan bagi negara-negara anggota mengenai perjanjian-perjanjian yang telah dicapai beserta lampiranlampirannya, termasuk keputusankeputusan yang ditentukan kemudian dalam perundingan tingkat menteri dan mengatur pelaksanaan ketentuan mengenai penyelesaian sengketa perdagangan. Selanjutnya, WTO juga mengatur mekanisme peninjauan kebijakan di bidang perdagangan serta menciptakan kerangka penentuan kebijakan ekonomi global berkerja sama dengan Dana Moneter Internasional (IMF) dan Bank Dunia (World Bank), serta badanbadan yang berafiliasi (Pasal 3 The Marrakesh Agreement Establishing the World Trade Organisation.).

WTO juga akan melakukan peninjauan atas implementasi perjanjian-perjanjian oleh setiap negara anggota dan menjatuhkan sanksi atas pelanggaranpelanggaran terhadap ketentuanketentuan dalam perjanjian. WTO memiliki alat untuk memaksa negara-negara anggota untuk mengikuti ketentuanketentuannya. Dengan fungsifungsi yang dimiliki oleh WTO tersebut, menjadikan WTO sekaligus sebagai forum bagi perundingan-perundingan selanjutnya di masa mendatang dalam perjanjian multilateral. Kehadiran WTO diharapkan dapat melaksanakan segala ketentuan yang telah ditetapkan yakni tetap pada perwujudan perdagangan bebas yang jujur, terbuka dan adil (Abdul Manan, 2014:198-199).

Ketentuan Pasal XVI ayat 4 Agreement Establishing the World Trade Organization menjadi indikator penting bagaimana WTO mewajibkan negara-negara anggotanya untuk menyesuaikan aturan-aturan atau hukum perdagangannya, dengan aturanaturan yang termuat dalam Annex perjanjian WTO. Pasal XVI juga mewajibkan negara anggotanya untuk menyesuaikan prosedur administratifnya sesuai dengan prosedur administratif WTO.

WTO telah memberlakukan berbagai perjanjian atau kesepakatan yang telah dibuat kepada negara-negara anggotanya terkait dengan kesepakatan pembentukan organisasi World Trade Organization (Marakesh Esthablishing the World Trade Organization), perdagangan barang (Multilateral Agreement on Trade in Goods), perdagangan jasa (General Agreement on Trade in Service), pengaturan tentang hak milik intelektual (Trade Related Aspects of Intellectual Property Right), 
prosedur penyelesaian sengketa (Dispute Settlement Understanding), perlakuan khusus bagi negara-negara berkembang (Generalized System of Preference), dan prinsip-prinsip perdagangan bebas lainnya (Munir Fuady, 2004:50).

Terdapat beberapa pengaturan dalam WTO yang disebut sebagai Basic Principle, antara lain General Agreement on Tariff and Trade (GATT) yang mengatur mengenai perdagangan barang, General Agreement on Tariff in Services (GATS) yang mengatur mengenai perdagangan jasa dan Agreement on Trade Related Aspects of Intellectual Property Rights (TRIPs) yang mengatur mengenai aspek perdagangan bebas dalam hubungan dengan Hak Milik Intelektual (Ibid:51).

Artikel VIII Marakesh Agreement menyebutkan bahwa status WTO sebagai organisasi internasional memiliki personalitas hukum atau legal personality untuk mengimplementasikan fungsi organisasi, ketentuan tersebut menyebutkan bahwa:

1. The WTO shall have legal personality, and shall be accorded by each of its Members such legal capacity as may be necessary for the exercise of its functions.

2. The WTO shall be accorded by each of its Members such privileges and immunities as are necessary for the exercise of its functions.

3. The officials of the WTO and the representatives of the
Members shall similarly be accorded by each of its Members such privileges and immunities as are necessary for the independent exercise of their functions in connection with the WTO.

4. The privileges and immunities to be accorded by a Member to the WTO, its officials, and the representatives of its Members shall be similar to the privileges and immunities stipulated in the Convention on the Privileges and Immunities of the Specialized Agencies, approved by the General Assembly of the United Nations on 21 November 1947.

5. The WTO may conclude a headquarters agreement.

Persetujuan-persetujuan WTO mencakup bidang pertanian, tekstil, dan pakaian, jasa keuangan, telekomunikasi, standarisasi industri, peraturan sanitary and phytosanitary, hak atas kekayaan intelektual dan lain-lain. Walaupun terdapat banyak persetujuan dalam WTO, beberapa prinsip dasar terkandung dalam persetujuanpersetujuan tersebut. Prinsipprinsip tersebut adalah dasar dari sistem perdagangan multilateral. Prinsip-prinsip tersebut antara lain:

1. Prinsip Most Favored Nation atau Nondiskriminasi

Berdasarkan prinsip Most Favored Nation dalam perjanjian WTO, semua negara diperlakukan sama. Negaranegara anggota WTO tidak boleh melakukan diskriminasi terhadap mitra dagangnya dan 
tidak boleh ada perbedaan perlakuan antara produk domestiknya dengan produk impor. Dengan demikian prinsip utama adalah bahwa konsesi yang diberikan kepada suatu negara mitra dagang harus berlaku pula bagi semua negara lainnya.

Satu negara tidak boleh diberi perlakuan lebih baik atau lebih buruk dari pada negara lain, dengan demikian maka semua negara ditempatkan pada kedudukan yang sama, dan semua negara harus turut menerima menikmati peluang yang tercapai dalam leberalisasi perdagangan internasional dan memikul kewajiban yang sama (H.S. Kartadjoemena, 2002:109). Beberapa pengecualian diperbolehkan seperti negaranegara anggota dapat membentuk persetujuan perdagangan bebas di mana tidak berlaku untuk barangbarang dari luar kelompok ini. Sebuah negara dapat mengenakan hambatan terhadap produk-produk negara tertentu yang dinilai tidak adil dalam melakukan perdagangan.

2. Prinsip National Treatment atau Perlakuan Nasional

Suatu negara harus memberikan perlakuan yang sama terhadap produksi dalam negeri dan terhadap produksi luar negeri. Dalam prinsip ini produk lokal maupun produk impor harus diperlakukan sama. Prinsip perlakuan sama dengan produk nasional ini meliputi bidang jasa, merek, undang-undang hak cipta dan hak paten. Misalnya, pajak penjualan yang sama akan dikenakan bagi produk serupa yang dijual orang asing dan yang diperdagangkan warga negara sendiri (Muhammad Sood, 2012:45). Prinsip ini juga berlaku terhadap semua macam pajak dan pungutan-pungutan lainnya serta terhadap perundang-undangan, pengaturan dan persyaratanpersyaratan (hukum) yang memengurusi penjualan, pembelian, pengangkutan, distribusi atau penggunaan produk di pasar dalam negeri. Prinsip ini juga memberikan perlindungan terhadap proteksionisme sebagai akibat upaya-upaya atau kebijakan administratif atau legislatif.

3. Prinsip Transparency atau transparansi

Negara anggota diwajibkan untuk bersikap terbuka atau transparan terhadap berbagai kebijakan perdagangannya sehingga memudahkan para pelaku usaha untuk melakukan kegiatan perdagangan. Untuk mendukung prinsip ini, negara anggota diharapkan untuk menotifikasi segala kebijakannya yang terkait dengan perdagangan barang, jasa, dan kekayaan intelektual (Ratya Anindita dan Michael R.Reed, 2008:68).

4. Prinsip Resiprositas

Prinsip yang mensyaratkan adanya perlakuan timbal balik diantara sesama negara anggota WTO dalam kebijaksanaan perdagangan internasional. 
Artinya, apabila suatu negara dalam kebijaksanaan perdagangan internasionalnya menurunkan tarif masuk atas produk impor dari suatu negara, maka negara yang mengekspor produk tersebut wajib juga menurunkan tarif masuk untuk produk dari negara pertama tadi (Muhammad Sood, 2012:45).

\section{World Trade Organization berperan bagi negara berkembang dalam sistem perdagangan antar negara.}

Negara-negara

berkembang mengharapakan dengan adanya Uruguay Round bahwa perundingan tersebut akan menghasilkan satu sistem perdagangan multilateral berlandaskan hukum yang lebih kuat, memiliki kekuasaan penuh untuk menyelesaikan sengketa dagang, lebih mampu memberikan bantuan untuk melaksanakan reformasi domestik, dan mengandung ketentuan-ketentuan khusus bagi kepentingan negaranegara berkembang dalam seluruh kesepakatan WTO. Sistem ini diharapkan dapat membebaskan negara-negara berkembang berpenghasilan rendah dari tekanan politik dan ekonomi negara-negara besar (Gofar Bain, 2001:232).

WTO memberikan pengaruh bagi perdagangan internasional terkait dengan adanya dorongan bagi persaingan bebas. WTO merupakan sistem yang mengatur kompetisi yang terbuka, adil (fair) dan sehat. Pemberlakuan prinsip MFN dan perlakuan nasional dirancang untuk mempertahankan perdagangan yang adil, termasuk pada masalah dumping dan subsidi. Pada intinya persetujuanpersetujuan ditujukan untuk mendukung kompetisi yang sehat di bidang perdagangan barang, pertanian, hak atas kekayaan intelektual dan jasa. Selain itu, WTO mendorong reformasi pembangunan dan ekonomi.

Para ahli ekonomi dan perdagangan mengakui bahwa sistem WTO dapat memberikan kontribusi pada pembangunan. Persetujuan-persetujuan WTO juga memuat aturan mengenai fleksibilitas yang diberikan kepada negara-negara berkembang dalam menerapkan ketentuan-ketentuan yang terdapat dalam WTO. Bahkan persetujaun-persetujuan tersebut juga memuat ketentuan yang memungkinkan negara-negara paling terbelakang (Least Developed Countries/LDCs) mendapat bantuan khusus serta konsesi dagang seperti halnya peraturan-peraturan GATT (Direktorat Perdagangan dan Perindustrian Multilateral, Direktorat Jenderal Multilateral Ekonomi Keuangan dan Pembangunan Departemen Luar Negeri, 2003:4).

Sekitar tiga perempat anggota WTO adalah negaranegara berkembang dan negaranegara dengan ekonomi dalam masa transisi menuju ekonomi pasar. Selama tujuh setengah tahun Putaran Uruguay, negara-negara telah melakukan liberalisasi perdagangan, sehingga mereka 
sangat aktif dan berpengaruh dalam negosiasi perdagangan jika dibandingkan dengan putaranputaran perundingan sebelumnya. Perkembangan ini menunjukkan bahwa sistem perdagangan multilateral tidak hanya diperuntukkan bagi negara-negara industri, tetapi juga bagi negara berkembang. Pada akhir Putaran Uruguay, negara-negara berkembang seperti halnya negaranegara maju, telah siap menjalankan persetujuanpersetujuan WTO walaupun dengan perbedaan tenggang waktu untuk masa implementasinya. Negara-negara maju juga diharuskan mempercepat pelaksanaan komitmen akses pasarnya bagi ekspor dari negara berkembang dan negara berkembang paling terbelakang serta meningkatkan bantuan teknis bagi negara-negara tersebut (Ibid). WTO juga meningkatkan prediktabilitas.

Pembentukan sistem perdagangan multilateral merupakan usaha anggota WTO untuk menciptakan lingkungan bisnis yang stabil dan dapat diprediksi. Dengan stabilitas dan kebijakan yang dapat diprediksi, maka investasi dapat dilakukan, lapangan pekerjaan diciptakan dan konsumen dapat memperoleh keuntungan dari sistem kompetisi yang adil. Di dalam WTO, bila suatu negara menyetujui membuka pasarnya untuk barang-barang dan jasa, hal ini berarti negara tersebut telah meningkatkan komitmennya. Untuk sektor barang-barang, tikatannya berupa tingkat tarif pabean tertinggi, tapi tetap dimungkinkan suatu negara untuk mengenakan bea masuk impor yang lebih rendah daripada komitmen tarif yang diikatnya (binding tariff). Hal ini sering dilakukan oleh negara-negara berkembang (Ibid).

Sebuah negara dapat mengubah komitmen tarifnya setelah melakukan negosiasi dengan mitra-mitra dagangnya dan memberikan kompensasi kepada mitra-mitra dagangnya yang dirugikan akibat perubahan komitmen tersebut. Salah satu hasil konkrit perundingan perdagangan multirateral Putaran Uruguay adalah meningkatnya perdagangan dengan bertambahnya komitmen tarif yang diikat. Untuk bidang pertanian, seluruh produk pertanian saat ini telah memiliki tarif yang diikat (bound tariffs). Hasil yang dicapai dari semua ini adalah tigkat keamanan pasar yang cukup substansial bagi para pelaku usaha dan investor (Ibid).

Contoh perdangan multilateral ini mencoba untuk meningkatkan prekdibilitas dan stabilitas perdagangan internasional. Salah satu cara adalah dengan mendiscourge penggunaan kuota untuk membatasi impor. Cara lain adalah dengan meningkatkan transparansi peraturan perdagangan suatu negara. Melalui sistem ini, dapat pula dibuat suatu aturan perdagangan yang jelas dan transparan. Banyak pasal-pasal dalam Persetujuan WTO yang mendorong pemerintah negara anggota agar menjelaskan kebijakan dan sasaran yang ingin 
ditujukan kepada publik dan melaporkannya kepada WTO. Pemantauan secara reguler kebijakan nasional perdagangan melalui mekanisme peninjauan kebijakan perdagangan (Trade Policy Review Mechanism) merupakan suatu sarana untuk meningkatkan keterbukaan baik pada tingkat domestik maupun pada tingkat multilateral (Ibid). Negara-negara

berkembang dalam mengatasi permasalahan-permasalahan

terkait dengan perdagangan antar negara agar sejalan dengan langkah-langkah penyesuaian yang dilakukan dalam kebijaksanaan domestik serta konsisten dengan sistem WTO. Negara-negara berkembang juga harus menerapkan sebagai prioritas persiapan-persiapan mereka untuk memasuki perundingan perdagangan multilateral. Sasaran yang harus dicapai oleh negaranegara berkembang adalah agar mereka dapat mengemukakan pandangan mereka secara efektif, dapat membela kepentingan nasional negara-negara mereka dalam WTO, dapat mempengaruhi penentuan arah perkembangan WTO di masa depan, dan dapat mempengaruhi perundingan perdagangan multilateral di masa depan.

Negara-negara
berkembang diharapkan dapat
membangun institusi dan
pengembangan sumber daya
manusia bagi kebijaksanaan
perdagangan dan hal tersebut
harus menjadi prioritas yang akan
dicapai melalui bantuan keuangan

dari luar negeri, kerjasama teknis, dan yang terpenting adalah dengan upaya negara-negara itu sendiri. Negara-negara berkembang harus melakukan identifikasi segala isu yang penting bagi negara-negara mereka. Sebagai contoh, mereka harus mengushakan perundingan mengenai tarif bea masuk dengan tujuan untuk menurunkan tariff peaks yang masih terdapat (tarif yang sangat tinggi untuk melindungi sektor-sektor sensitif) di negara-negara maju. Selain itu untuk mengurangi tingkat proteksi yang relatif tinggi di sejumlah negara-negara berkembang yang sudah snagat maju. Selanjutnya, untuk menurunkan tariff escalation di semua negara mitra dagang dan yang berpotensi menjadi mitra dagang.

Sistem perdagangan WTO memberikan keuntungan terkait sistem perdagangan multilateral WTO yang mendorong terciptanya perdamaian, persengketaan antar negara dapat ditangani secara konstruktif, peraturan-peraturan yang sesuai dengan sistem multilateral akan memudahkan perdagangan antar negara, sistem perdagangan multilateral mendorong pengurangan tarif dan hambatan non tariff sehingga biaya hidup menjadi lebih murah, sistem perdagangan multilateral memberikan banyak pilihan atas produk dengan kualitas berbeda kepada konsumen, sistem perdagangan multilateral meningkatkan pendapatan, sistem perdagangan multilateral mendorong pertumbuhan 
ekonomi, prinsip-prinsip dasar sistem perdagangan WTO bila secara konsisten diterapkan akan mendorong perdagangan berjalan lebih efisien, pemerintah negaranegara anggota akan terlindungi dari praktik-praktik persaingan dagang antar negara yang tidak sehat, dan sistem perdagangan multilateral mendorong terciptanya pemerintahan yang bersih.

\section{Kesimpulan}

1. Ketentuan Pasal XVI ayat 4 Agreement Establishing the World Trade Organization menjadi indikator penting bagaimana WTO mewajibkan negara-negara anggotanya untuk menyesuaikan aturanaturan atau hukum perdagangannya, dengan aturan-aturan yang termuat dalam Annex perjanjian WTO. Bahkan ketentuan Pasal XVI tersebut juga mewajibkan negara anggotanya untuk menyesuaikan prosedur administratifnya sesuai dengan prosedur administratif WTO. Terdapat beberapa pengaturan dalam WTO yang disebut sebagai Basic Principle, antara lain General Agreement on Tariff and Trade (GATT) yang mengatur mengenai perdagangan barang, General Agreement on Tariff in Services (GATS) yang mengatur mengenai perdagangan jasa dan Agreement on Trade Related Aspects of Intellectual Property Rights (TRIPs) yang mengatur mengenai aspek perdagangan bebas dalam hubungan dengan Hak Milik Intelektual. Artikel VIII Marakesh Agreement menyebutkan bahwa status WTO sebagai organisasi internasional memiliki personalitas hukum atau legal personality untuk mengimplementasikan fungsi organisasi, ketentuan tersebut menyebutkan bahwa "The WTO shall have legal personality, and shall be accorded by each of its Members such legal capacity as may be necessary for the exercise of its functions. The WTO shall be accorded by each of its Members such privileges and immunities as are necessary for the exercise of its functions. The officials of the WTO and the representatives of the Members shall similarly be accorded by each of its Members such privileges and immunities as are necessary for the independent exercise of their functions in connection with the WTO. The privileges and immunities to be accorded by a Member to the WTO, its officials, and the representatives of its Members shall be similar to the privileges and immunities stipulated in the Convention on the Privileges and Immunities of the Specialized Agencies, approved by the General Assembly of the United Nations on 21 November 1947. The WTO may conclude a headquarters agreement."

2. WTO memberikan pengaruh bagi perdagangan internasional terkait dengan 
$\begin{array}{lrr}\text { adanya } & \text { dorongan } & \text { bagi } \\ \text { persaingan } & \text { bebas. } & \text { WTO } \\ \text { merupakan } & \text { sistem } & \text { yang } \\ \text { mengatur } & \text { kompetisi } & \text { yang }\end{array}$ terbuka, adil (fair) dan sehat. Selain itu, sistem WTO dapat memberikan kontribusi pada pembangunan. Persetujuanpersetujuan WTO juga memuat aturan mengenai fleksibilitas yang diberikan kepada negaranegara berkembang dalam menerapkan ketentuanketentuan WTO. Bahkan persetujaun-persetujuan

tersebut juga memuat ketentuan yang memungkinkan negara-negara paling terbelakang (Least Developed Countries/LDCs) mendapat bantuan khusus serta konsesi dagang seperti halnya peraturan-peraturan GATT. Selanjutnya, WTO juga meningkatkan prediktabilitas. Pembentukan sistem perdagangan multilateral merupakan usaha anggota WTO untuk menciptakan lingkungan bisnis yang stabil dan dapat diprediksi. Dengan stabilitas dan kebijakan yang dapat diprediksi, maka investasi dapat dilakukan, lapangan pekerjaan diciptakan dan konsumen dapat memperoleh keuntungan dari sistem kompetisi yang fair. Sistem perdagangan WTO memberikan keuntungan terkait sistem perdagangan multilateral WTO yang mendorong terciptanya perdamaian, persengketaan antar negara dapat ditangani secara konstruktif, peraturanperaturan yang sesuai dengan sistem multilateral akan memudahkan perdagangan antar negara, sistem perdagangan multilateral mendorong pengurangan tarif dan hambatan non tariff sehingga biaya hidup menjadi lebih murah.

\section{Saran - Saran}

1. Negara-negara berkembang dalam mengatasi permasalahan-permasalahan terkait dengan perdagangan antar negara agar sejalan dengan langkah-langkah penyesuaian yang dilakukan dalam kebijaksanaan domestik dan konsisten dengan sistem GATT-WTO. Negara-negara berkembang juga harus menerapkan sebagai prioritas persiapan-persiapan untuk menghadapi perundinganperundingan yang dilakukan terkait perdagangan multilateral.

2. Negara-negara berkembang diharapkan dapat membangun institusi dan pengembangan sumber daya manusia bagi kebijaksanaan perdagangan dan hal tersebut harus menjadi prioritas yang akan dicapai melalui bantuan keuangan dari luar negeri, kerjasama teknis, dan yang terpenting adalah dengan upaya negara-negara itu sendiri.

\section{Daftar Pustaka}

Buku

Adolf, Huala, 2002, Hukum Ekonomi Internasional

Suatu 
Pengantar, Rajawali Pers, Jakarta.

$$
\text { , 2004, Penyelesaian }
$$

Sengketa Dagang dalam World Trade Organization (WTO), Sinar Grafika, Jakarta.

(WTO), 2005, Hukum
Perdagangan Internasional, Rajagrafindo Persada, Jakarta.

Anindita, Ratya dan Michael R.Reed, 2008, Bisnis dan Perdagangan Internasional, Andi Offset, Yogyakarta.

August, Ray, 2000, International Business Law: Text, Case, and Readings, Prentice Hall, New Jersey.

Braithwaite, John dan Peter Drahos, 2000, Global Business Regulation, Cambridge University Press, New York.

Bain, Gofar, 2001, Uruguay Round dan Sistem Perdagangan Masa Depan, Djambatan, Jakarta.

Bossche, Peter Van Den, 2005, The Law and Policy of the World Trade Organization: Text, Cases and Materials, Cambridge University Press, New York.

Bossche, Peter Van Den, dkk, 2010, Pengantar Hukum WTO (World Trade Organization), Yayasan Obor Indonesia, Jakarta.

Bhala, Raj, 2001, International trade law, Theory and Practice, Lexis Publishing, New York.

Dominick, Salvatore, 2007, Trade as Engine of Growth, Cambrige Journal of Economic, Erlangga Jakarta.
Fajar, Mukti dan Yulianto Achmad, 2010, Dualisme Penelitian Hukum Normatif \& Empiris, Pustaka Pelajar, Yogyakarta.

Fuady, Munir, 2004, Hukum Dagang Internasional (Aspek Hukum dari WTO), Citra Aditya Bakti, Bandung.

Hata, "Partisipasi Negara Berkembang Pada Proses Hukum di WTO : Antara Harapan dan Permasalahan", Jurnal Hukum Bisnis, Vol. 26, No. 2, 2007.

Hamidi, M. Luthfi, 2007, Gold Dinar, Sistem Moneter Global yang Stabil dan Berkeadilan, Senayan Abadi Publishing, Jakarta.

Hanitijo, Ronny, 1991, Metode Penelitian Hukum, Cetakan ke II, Ghalia Indo, Jakarta.

Jackson, John H., 2000, The World Trading System, MIT Press, Cambridge.

Jhamtani, Hira, 2005, WTO dan Penjajahan Kembali Dunia Ketiga, INSISTpress, Yogyakarta.

Kartadjoemena, H.S., 2000, Substansi Perjanjian GATT / WTO dan Mekanisme Penyelesaian Sengketa, system, Kelembagaan, Prosedur, Implementasi, dan Kepentingan Negara Berkembang, Universitas Indonesia press, Jakarta. , 2002, GATT dan WTO. Sistem, Forum Dan Lembaga Internasional Di Bidang Perdagangan, Universitas Indonesia Press, Jakarta. 
Manan, Abdul, 2014, Peranan Hukum dalam Pembangunan Ekonomi, Kencana Prenada Media Group, Jakarta.

Nopirin, 2000, Ekonomi Internasional, BPFE - UGM, Yogyakarta.

Pandika, Rusli, 2010, Sanksi Dagang Unilateral di Bawah Sistem Hukum WTO, PT. Alumni, Bandung.

Posner, Richard A., 1999, The Problematic of Moral and Legal Theory, The Belknap Press of Harvard University Press, London.

Reuvid, Jonathan, 1997, The Strategic Guide to International Trade, Kogan Page, London.

Sood, Muhammad, 2012, Hukum perdagangan internasional, Raja Grafindo Persada, Jakarta.

Syahmin, 2006, Hukum Dagang Internasional, Rajagrafindo Persada, Jakarta.

Schmitthoff, 1968, The Unification of the Law of International Trade, JBL.

Tobing, PH.OL., 1977, Hukum Pelayaran dan Perdagangan Amanna Gappa, Yayasan Kebudayaan Sulawesi Selatan, Ujung Pandang.

Yerxa, Rufus dan Bruce Wilson, ed, 2005, Key Issues In WTO Dispute Settlement The First Ten Years, Cambridge University Press, Cambridge.

\section{Artikel dan Jurnal}

Barutu, Christhophorus, "Sejarah Sistem Perdagangan Internasional (Dari Upaya Pembentukan Internasional
Trade Organization, Eksistensi General Agreement On Tariffs and TradeSampai Berdirinya World Trade Organization", Jurnal Hukum Gloris Juris, Fakultas Hukum Universitas Katholik Atmajaya, Volume 7, Nomor 1, 1 Januari 2007, Jakarta.

Darton, James E., "The Coming of The Global Trademark: The Effect of Trips On The WellKnown Marks Exception To The Principle of Territoriality", Michigan State International Law Review, Volume 11, 2011.

Hodges, Kevin E. dan Daniel P. Sulmasy, "Moral Status, Justice, and the Common Morality: Challenges for the Principlist Account of Moral Change", Kennedy Institute of Ethics Journal, Vol. 23, Number 3, September 2013.

\section{Dokumen}

Hidayat, Mochamad Slamet, et.al., Sekilas WTO (World Trade Organization), Edisi Keempat, Direktorat Perdagangan, Perindustrian, Investasi dan HKI Direktorat Jenderal Multilateral Departemen Luar Negeri, Jakarta.

United Nations, 1966, Progressive Development of the Law of International Trade: Report of the Secretary-General of the United Nations, hlm. 20. Lihat juga Chia-Jui Cheng (ed), 1988, Clive M. Schmitthoff's Select Essay on International 
Trade Law, Martinus Nijhoff \& Graham \& Trotman, London. Uruguay Round Trade Agreement, Statement of Administrative Action, Agreement Establishing the World Trade Organization, H.R. Doc. No. 316, 103d Cong., 2d Sess, 656667, September 27, 1994.

\author{
Instrumen Hukum \\ The Marrakesh Agreement \\ Establishing the World Trade \\ Organisation. Signed at the \\ Maerrakesh \\ ministerial \\ meeting in April 1994
}

